\title{
Synthesis and Characterization of Mixed Ligand Complexes of Co(II) and Fe(III) Ions with Malic Acid and Heterocyclic Amines
}

\author{
Md. Belayet Hossain ${ }^{1}$, M. A.Yousuf ${ }^{*}$, M. Rafiqul Islam ${ }^{2}$, Md Abdus Salam ${ }^{3}$, Mohammad Arifur Rahman ${ }^{3}$ \\ and Md. Ahedul Akbor ${ }^{4}$ \\ ${ }^{1}$ Department of Chemistry, Khulna University of Engineering \& Technology, Khulna-9203, Bangladesh. \\ ${ }^{2}$ Department of Botany, Shahzadpur Government Collage, Sirajgang , Bangladesh \\ ${ }^{3}$ Department of Chemistry, University of Dhaka, Dhaka-1000, Bangladesh \\ ${ }^{4}$ Analytical Research Division, Bangladesh Council of Scientific \& Industrial Research, Dhaka, Bangladesh
}

\begin{abstract}
This paper describes the preparation and characterization of mixed ligand complexes of $\mathrm{Co}(\mathrm{II})$ and $\mathrm{Fe}(\mathrm{III})$ ions with malic acid and heterocyclic amines. The general formula of the complexes are as follows: $\left[M(M A) L_{2}\right]$ and $\mathrm{K}\left[\mathrm{M}(\mathrm{MA})_{2} \mathrm{~L}_{2}\right]$ (where, $\mathrm{M}=\mathrm{Co}(\mathrm{II})$ (1-4), $\mathrm{Fe}(\mathrm{II})$ (5-8); $\mathrm{MA}=\mathrm{C}_{4} \mathrm{H}_{4} \mathrm{O}_{5}$ (1-4), $2 \mathrm{C}_{4} \mathrm{H}_{4} \mathrm{O}_{5}$ (5-8); $\mathrm{L}=\mathrm{C}_{6} \mathrm{H}_{5} \mathrm{~N}$ (1), $\mathrm{C}_{6} \mathrm{H}_{7} \mathrm{~N}$ (2), $\mathrm{C}_{9} \mathrm{H}_{7} \mathrm{~N}(3,4), 2 \mathrm{C}_{6} \mathrm{H}_{5} \mathrm{~N}$ (5), $2 \mathrm{C}_{6} \mathrm{H}_{7} \mathrm{~N}$ (6), $2 \mathrm{C}_{9} \mathrm{H}_{7} \mathrm{~N}$ (7-8). The complexes were prepared in the solid form and characterized by elemental analysis, conductivity and magnetic measurements, infrared and electronic spectroscopic studies. The infrared spectra of the complexes confirmed the coordination of metal ion with ligands. The Co(II) complexes are assumed to have tetrahedral and the Fe(III) complexes have octahedral structure based on the electronic spectra and magnetic measurements. Their antibacterial and antifungal activity has also been evaluated by the disc diffusion methods against fourteen pathogenic bacteria (five gram positive and nine gram negative) and fourteen fungi. Complexes [Co(II)(MA)(4-pico $\left.)_{2}\right]$ showed the highest antibacterial activity against all bacteria tested (when, $\mathrm{MA}=\mathrm{C}_{4} \mathrm{H}_{4} \mathrm{O}_{5}$ and 4-pico $=\mathrm{C}_{6} \mathrm{H}_{7} \mathrm{~N}$ ).
\end{abstract}

Key words: $\mathrm{Co}(\mathrm{II})$ and $\mathrm{Fe}(\mathrm{III})$ complexes, Malic Acid, Heterocyclic Amines, Antimicrobial activities.

\section{Introduction}

An exhaustive survey of the existing literature reveals that a very little study has been conducted on the metal complexes of dibasic acid. Islam and co-workers reported the magnetic properties of some carboxylic acid derivatives of cobalt (II) and iron(III) (Islam et al., 2004). Novel Malonato-Bridged copper(II) complexes were prepared and characterized by elemental analyses, electronic spectra, magnetic susceptibilities, and X-ray analysis (Catalina et al., 2000). Synthetic chemicals constitute important sources of various bioactive compounds such as antibacterial (Zakaria et al., 2000), antifungal (Islam et al., 2002) and anticancer (Part et al., 1979) compounds. The metal complexes of phthalic acid have been studied both from pharmacological (Sultana et al., 2003) and industrial (Nippon Synthetic Chemical Industry Co. Ltd. Japan, 1980) point of view as indicated by available literature. Some complexes of transition metal ion with malonic (Bhatia et al., 1993 and Reza et al., 2003), phathalic (Sultana et al., 2003; Reza et al., 2003) and maleic (Islam et al., 2003) acid have been found medicinally important.

Considering these facts, the present work describes the preparation, characterisation and antimicrobial screening of mixed ligand complexes of $\mathrm{Co}(\mathrm{II})$ and $\mathrm{Fe}(\mathrm{III})$ with malic acid $\left(\mathrm{MAH}_{2}\right)$ as primary and heterocyclic amines, viz. quinoline (Q), iso-quinoline (IQ), pyridine (Py), 4-picoline (4-pico) as secondary ligands on the basis of various physico-chemical techniques.

\section{Materials and Methods}

All the chemicals were of reagent grade unless otherwise specified and were used as received. The solvents were purified using conventional methods.

Physical measurement: Infrared spectra were recorded on FTIR spectrophotometer (IR-Prestrige-21) in the region $4500-400 \mathrm{~cm}^{-1}$ at the Department of Chemistry, University of Dhaka, Bangladesh. Carbon, hydrogen and nitrogen analyses were carried out at the Center for Advance Research on Sciences(CARS), University of 
Dhaka, Bangladesh. Metal was determined by weighing as the oxide produced by direct ignition (Scargill, 1961). The molar conductance at $10^{-3} \mathrm{M}$ solutions of the metal complexes in DMF was measured at $30{ }^{\circ} \mathrm{C}$ using conductivity meter. Melting points were determined using an electrothermal digital melting point apparatus. Magnetic susceptibility was measured with Magnetic Susceptibility Balance (Model: Mk1, Sherwood Scientific, Cambridge, England) at the department of chemistry, University of Dhaka, Bangladesh at $298{ }^{\circ} \mathrm{K}$. All susceptibilities were corrected for diamagnetic contribution using Pascal's constant (Vogel 1961).

Preparation of $\mathrm{Co}(\mathrm{II})$ complexes: The freshly prepared cobalt (II) chloride salt $(4.0 \mathrm{~m} \mathrm{~mol})$ and malic acid $(4.0 \mathrm{~m} \mathrm{~mol}$ ) were mixed in $100 \mathrm{~mL}$ of absolute ethanol and refluxed on a water bath for an hour and then the calculated amount of an alcoholic solution of heteroamine bases was added (e.g. $8.0 \mathrm{~m} \mathrm{~mol}$ of Py, Q, IQ and 4-pico). The mixture was again refluxed for an hour and then cooled. The precipitate formed were filtered, washed several times with ethanol and then dried in vacuum over phosphorus pentoxide $\left(\mathrm{P}_{2} \mathrm{O}_{5}\right)$.

Preparation of $\mathrm{Fe}(\mathrm{III})$ complexes: An ethanolic solution (just dissolved) of $\mathrm{Fe}(\mathrm{III})$ chloride $(2.0 \mathrm{~m} \mathrm{~mol})$ and malic acid $(4.0 \mathrm{~m} \mathrm{~mol})$ were mixed in the calculated ratio with constant stirring for 30 minutes. No precipitate was observed after which heteroamine bases (e.g. $4.0 \mathrm{~m}$ mol of Q, IQ, Py, 4-pico) was added with constant stirring for an hour. Finally, the solution of complexes was prepared in one equivalent of alcoholic potassium hydroxide. The precipitates were filtered, washed several times with alcohol and then dried in a vacuum desiccator over phosphorus pentoxide $\left(\mathrm{P}_{2} \mathrm{O}_{5}\right)$.

Antimicrobial activities: Fourteen pathogenic bacteria as listed in Table 6 were collected from the Department of Pharmacy and Department of Botany, University of Rajshahi respectively and selected for antimicrobial test. The tests were performed at the Plant Pathology Laboratory, Department of Botany, University of Rajshahi. Nutrient agar and potato dextrose agar were used as bacteriological and fungal growth media respectively. The complexes were dissolved separately in dimethyl sulfoxide (DMSO) to get a concentration of 200$\mu \mathrm{g} \operatorname{disc}^{-1}$. Then in vitro anti-microbial activity of these complexes was carried out by disc diffusion method (Beur et al., 1966; Rios et al., 1988). Diameter of zone of inhibition produced by the complexes was compared with Kanamycin (30- $\left.\mu \mathrm{g} \mathrm{disc}^{-1}\right)$ and Fluconazol $\left(200-\mu \mathrm{g} \mathrm{disc}^{-1}\right)$ for bacteria and fungi respectively.

\section{Results and Discussion}

Elemental analyses and conductivity measurements: Elemental analyses along with other data and their physical properties are presented in Tables- $\mathbf{1}$ and $\mathbf{2}$. The molar conductances were measured in $\mathrm{N}, \mathrm{N}^{\prime}$-dimethylformamide. The conductance values (Table 1) indicate that the complexes (1-4) are non-electrolyte in nature, while the complexes (5-8) behave as 1:1 electrolytes.

Magnetic moments: The effective magnetic moment of the $\mathrm{Co}(\mathrm{II})$ and $\mathrm{Fe}(\mathrm{III})$ complexes at room temperature are shown in Table $\mathbf{1}$. The magnetic measurements indicate that the $\mathrm{Co}(\mathrm{II})$ complexes (1-4) are paramagnetic and show magnetic moment between 3.72-4.05BM corresponding to three unpaired electrons and hence, are tetrahedral with $\mathrm{sp}^{3}$ hybridization. The observed magnetic moment values of $\mathrm{Fe}(\mathrm{III})$ (5.68 - 5.93 BM.) indicate that complexes are also paramagnetic with five unpaired electron and therefore, are octahedral structure with $\mathrm{sp}^{3} \mathrm{~d}^{2}$ hybridization (Islam et al., 2004).

Infrared spectral studies: The complexes display $v_{\mathrm{C}=\mathrm{O}}$ band at 1558.4-1625.5 $\mathrm{cm}^{-1}$ and $v_{\mathrm{C}-\mathrm{O}}$ band at 1342.4$1379.0 \mathrm{~cm}^{-1}$, significantly lower than the values of free malonic acid (1700 and $1440 \mathrm{~cm}^{-1}$ ), which indicate the coordination of malic acid through their carboxylate anions. Further, the presence of $\mathrm{M}-\mathrm{O} \quad(\mathrm{O}=$ Oxygen in deprotonated malonic acid) bonding is evident from the appearance of $v_{\mathrm{M}-\mathrm{O}}$ modes at $446.5-498.6 \mathrm{~cm}^{-1}$ in the spectra of the complexes. The broad band observed at $3400-3600 \mathrm{~cm}^{-1}$ due to $v_{\mathrm{O}-\mathrm{H}}$ of free malic acid or free $-\mathrm{OH}$ was disappeared on complexation indicating the metaloxygen linkage. The extra broad band at $\sim 3500 \mathrm{~cm}^{-1}$ in the spectrum of the complexes may be due to uncoordinated $\mathrm{OH}$ group. The characteristic ring vibration of the heterocyclic amines in the ring $1400-1600 \mathrm{~cm}^{-1}$ generally show significant changes on complexation but in our present complexes these bands could not be distinguished because of overlapping with $v_{\mathrm{C}=\mathrm{O}}$ and $v_{\mathrm{C}-\mathrm{O}}$ stretching bands. In plane and out of plane ring deformation modes of the heterocyclic amines observed at $\sim 520$ and $\sim 720 \mathrm{~cm}^{-}$ ${ }^{1}$ respectively (Hossain et al., 2004, 2008; Shekh et al., 
2004). Major IR spectral data for the complexes are given in Table 3.

Electronic spectra: The electronic spectra of $\mathrm{Co}(\mathrm{II})$ complexes (1-4) gave two intense bands at 24000-24500 and 30000-30154 cm $\mathrm{cm}^{-1}$ corresponding to the transition ${ }^{4} \mathrm{~A}_{2 \mathrm{~g}}$ $(\mathrm{F}) \rightarrow{ }^{4} \mathrm{~T}_{1 \mathrm{~g}}(\mathrm{P})\left(v_{3}\right)$ and charge transfer band respectively. These spectra indicated the tetrahedral stereochemistry of Co(II) complexes. Table 4 contains the data of electronic spectra of Co(II) complexes (Reza et al., 2003).

The electronic spectra of Fe(III) complexes (5-8) gave four bands at the range 18500-18725, 21000-21185, $24325-24750$ and $25770-25640 \mathrm{~cm}^{-1}$ corresponding to the transitions -

$\begin{array}{lll}{ }^{6} \mathrm{~A}_{1 \mathrm{~g}} & \rightarrow & { }^{4} \mathrm{~T}_{1 \mathrm{~g}}(\mathrm{G}) \\ { }^{6} \mathrm{~A}_{1 \mathrm{~g}} & \rightarrow & { }^{4} \mathrm{~T}_{2 \mathrm{~g}}(\mathrm{G}) \\ { }^{6} \mathrm{~A}_{1 \mathrm{~g}} & \rightarrow & { }^{4} \mathrm{E}_{\mathrm{g}}(\mathrm{G}) \\ { }^{6} \mathrm{~A}_{1 \mathrm{~g}} & \rightarrow & { }^{4} \mathrm{~A}_{1 \mathrm{~g}}(\mathrm{G})\end{array}$

respectively. These spectra indicated the octahedral stereochemistry of $\mathrm{Fe}(\mathrm{III})$ compound (Reza et al., 2003 and Islam et al., 2003). Table 5 contains the data of electronic spectra of Fe(III) complexes.

On the basis of the above discussion the possible structure of the complexes $(\mathbf{1 , 6 )}$ are given in the Figures 1 and 2 respectively.

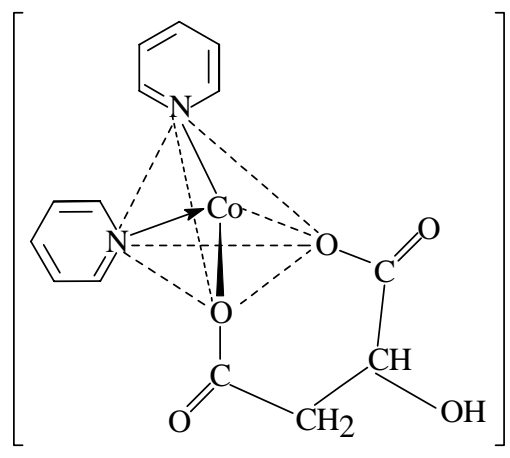

Figure 1. Possible structure of [Co(II)(MA)(py) $\left.)_{2}\right]$ complex

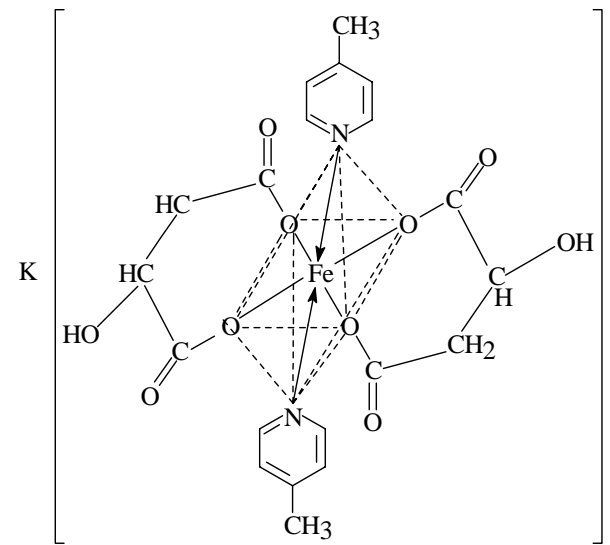

Figure 2. Possible structure of $\mathrm{K}\left[\mathrm{Fe}(\mathrm{III})(\mathrm{MA})_{2}(4-\mathrm{pico})_{2}\right]$ complex

Antimicrobial activities: The antibacterial activities of these complex compounds were studied and result were presented in Table $\mathbf{6}$. The highest zone of inhibition 21, $30,22,24,19,28,20$ and $18 \mathrm{~mm}$ were produced by $S$. boydii, $S$. dysenteriae, B. megaterium, S. shiga, $S$. dysenteriae, S. shiga, S. typhi and B. megaterium respectively. No inhibition zone was found against some bacteria. In the other cases, the complexes showed moderate zone of inhibition. It is evident from the Table to that the complex no. 2 has most and complex no. 7 has least antibacterial effect.

The antifungal activity of these complexes were also studied and result are presented in Table 7. In the case of antifungal activity tells the highest zone of inhibition 28 and $30 \mathrm{~mm}$ against Trichophyton sp and Bipolaris sorokiniana respectively were measured in complex no. 2 while rest of the complexes have more or less moderate antifungal effect against the tested fungi Aspergillus nidulans, Candida albicans and Colletotrichum falcatum. No zone of inhibition was found in some of the tested complexes.

Table 1. Physical properties of the complexes (1-8)

\begin{tabular}{|c|c|c|c|c|c|}
\hline $\begin{array}{l}\text { Com. } \\
\text { No. }\end{array}$ & Complexes & Color & $\begin{array}{l}\text { Melting point or } \\
\text { decomposition } \\
\text { temperature }\left( \pm 5^{\circ} \mathrm{C}\right)\end{array}$ & $\begin{array}{l}\text { Molar conductance } \\
\left(\mathrm{ohm}^{-1} \mathrm{~cm}^{2} \mathrm{~mol}^{-1}\right)\end{array}$ & $\begin{array}{l}\text { magnetic moment } \\
\text { (BM.) }\end{array}$ \\
\hline 1 & {$\left[\mathrm{Co}(\mathrm{II})(\mathrm{MA})(\mathrm{Py})_{2}\right]$} & Purple & 290 & 9.87 & 3.98 \\
\hline 2 & {$\left[\mathrm{Co}(\mathrm{II})(\mathrm{MA})(4-\mathrm{pico})_{2}\right]$} & Light purple & 290 & 11.93 & 3.72 \\
\hline 3 & {$\left[\mathrm{Co}(\mathrm{II})(\mathrm{MA})(\mathrm{Q})_{2}\right]$} & Light purple & 190 & 14.58 & 4.05 \\
\hline 4 & {$\left[\mathrm{Co}(\mathrm{II})(\mathrm{MA})(\mathrm{IQ})_{2}\right]$} & Light purple & 180 & 12.13 & 3.91 \\
\hline 5 & $\mathrm{~K}\left[\mathrm{Fe}(\mathrm{III})(\mathrm{MA})_{2}(\mathrm{py})_{2}\right]$ & Yellow & 220 & 65.89 & 5.78 \\
\hline 6 & $\mathrm{~K}\left[\mathrm{Fe}(\mathrm{III})(\mathrm{MA})_{2}(4-\text { pico })_{2}\right]$ & Yellow & 190 & 79.63 & 5.68 \\
\hline 7 & $\mathrm{~K}\left[\mathrm{Fe}(\mathrm{III})(\mathrm{MA})_{2}(\mathrm{Q})_{2}\right]$ & Cream & 185 & 72.81 & 5.82 \\
\hline 8 & $\mathrm{~K}\left[\mathrm{Fe}(\mathrm{III})(\mathrm{MA})_{2}(\mathrm{IQ})_{2}\right]$ & Cream & 180 & 69.86 & 5.93 \\
\hline
\end{tabular}


Table 2. Elemental analyses data of the complexes(1-8)

\begin{tabular}{clccccc}
\hline Com. No. & \multicolumn{1}{c}{ Complexes } & Yields $\%$ & Metal \% & Carbon \% & Hydrogen \% & Nitrogen \% \\
\hline 1. & {$\left[\mathrm{Co}(\mathrm{II})(\mathrm{MA})(\mathrm{Py})_{2}\right]$} & 63 & $16.88(16.76)$ & $48.15(48.09)$ & $4.04(4.01)$ & $8.02(8.05)$ \\
2. & {$\left[\mathrm{Co}(\mathrm{II})(\mathrm{MA})(4-\mathrm{pico})_{2}\right]$} & 59 & $15.62(15.55)$ & $50.93(50.82)$ & $4.81(4.92)$ & $7.43(7.33)$ \\
3. & {$\left[\mathrm{Co}(\mathrm{II})(\mathrm{MA})(\mathrm{Q})_{2}\right]$} & 65 & $13.11(13.02)$ & $58.80(58.73)$ & $4.04(3.96)$ & $6.24(6.18)$ \\
4. & {$\left[\mathrm{Co}(\mathrm{II})(\mathrm{MA})(\mathrm{IQ})_{2}\right]$} & 56 & $13.11(13.05)$ & $58.80(58.73)$ & $4.04(4.01)$ & $6.24(6.16)$ \\
5. & $\mathrm{~K}\left[\mathrm{Fe}(\mathrm{III})(\mathrm{MA})_{2}(\mathrm{py})_{2}\right]$ & 72 & $10.80(10.73)$ & $41.79(41.71)$ & $3.50(3.38)$ & $5.42(5.38)$ \\
6. & $\mathrm{~K}\left[\mathrm{Fe}(\mathrm{III})(\mathrm{MA})_{2}(4-\mathrm{pico})_{2}\right]$ & 69 & $10.24(10.19)$ & $44.04(44.09)$ & $4.05(4.09)$ & $5.14(5.03)$ \\
7. & $\mathrm{~K}\left[\mathrm{Fe}(\mathrm{III})(\mathrm{MA})_{2}(\mathrm{Q})_{2}\right]$ & 73 & $9.05(9.01)$ & $50.57(50.48)$ & $3.60(3.52)$ & $4.58(4.48)$ \\
8. & $\mathrm{~K}\left[\mathrm{Fe}(\mathrm{III})(\mathrm{MA})_{2}(\mathrm{IQ})_{2}\right]$ & 71 & $9.05(9.09)$ & $50.57(50.61)$ & $3.60(3.58)$ & $4.54(4.44)$ \\
\hline
\end{tabular}

Table 3. Infrared spectral data of the complexes(1-8) (band maxima in $\mathrm{cm}^{-1}$ )

\begin{tabular}{lllllll}
\hline \multicolumn{1}{c}{ Com. No. } & Complexes & $v(\mathrm{OH})$ & $v(\mathrm{C}=\mathrm{O})$ & $v(\mathrm{C}-\mathrm{O})$ & $v(\mathrm{M}-\mathrm{O})$ & $v(\mathrm{M}-\mathrm{N})$ \\
\hline 1 & {$\left[\mathrm{Co}(\mathrm{II})(\mathrm{MA})(\mathrm{Py})_{2}\right]$} & 3508.5 & 1599.8 & 1371.3 & 515.9 & 409.8 \\
2 & {$\left[\mathrm{Co}(\mathrm{II})(\mathrm{MA})(4-\mathrm{pico})_{2}\right]$} & 3517.8 & 1608.5 & 1342.4 & 568.0 & 416.1 \\
3 & {$\left[\mathrm{Co}(\mathrm{II})(\mathrm{MA})(\mathrm{Q})_{2}\right]$} & 3507.3 & 1595.0 & 1377.1 & 488.0 & 400.2 \\
4 & {$\left[\mathrm{Co}(\mathrm{II})(\mathrm{MA})(\mathrm{IQ})_{2}\right]$} & 3505.9 & 1625.9 & 1366.5 & 518.8 & 402.1 \\
5 & $\mathrm{~K}\left[\mathrm{Fe}(\mathrm{III})(\mathrm{MA})_{2}(\mathrm{py})_{2}\right]$ & 3520.2 & 1558.4 & 1373.2 & 574.7 & 415.2 \\
6 & $\mathrm{~K}\left[\mathrm{Fe}(\mathrm{III})(\mathrm{MA})_{2}(4-\mathrm{pico})_{2}\right]$ & 3515.6 & 1577.7 & 1379.0 & 504.4 & 412.7 \\
7 & $\mathrm{~K}\left[\mathrm{Fe}(\mathrm{III})(\mathrm{MA})_{2}(\mathrm{Q})_{2}\right]$ & 3514.6 & 1576.7 & 1379.0 & 504.4 & 411.8 \\
8 & $\mathrm{~K}\left[\mathrm{Fe}(\mathrm{III})(\mathrm{MA})_{2}(\mathrm{IQ})_{2}\right]$ & 3512.8 & 1599.6 & 1365.3 & 505.2 & 402.1 \\
\hline
\end{tabular}

Table 4. Electronic spectral data of Co(II) complexes(1-4)

\begin{tabular}{llcr}
\hline \multirow{2}{*}{ Com. No. } & Complexes & \multicolumn{2}{c}{ Spectral band $\left(\mathrm{cm}^{-1}\right)$ with assignment } \\
\cline { 3 - 4 } & & ${ }^{4} \mathrm{~A}_{2 \mathrm{~g}}(\mathrm{~F}) \rightarrow{ }^{4} \mathrm{~T}_{1 \mathrm{~g}}(\mathrm{P})\left(\mathrm{v}_{3}\right)$ & 30045 \\
\hline 1 & {$\left[\mathrm{Co}(\mathrm{II})(\mathrm{MA})(\mathrm{Py})_{2}\right]$} & 24039 & 30070 \\
2 & {$\left[\mathrm{Co}(\mathrm{II})(\mathrm{MA})(4-\mathrm{pic0})_{2}\right]$} & 24500 & 29948 \\
3 & {$\left[\mathrm{Co}(\mathrm{II})(\mathrm{MA})(\mathrm{Q})_{2}\right]$} & 23950 & 29860 \\
4 & {$\left[\mathrm{Co}(\mathrm{II})(\mathrm{MA})(\mathrm{IQ})_{2}\right]$} & 23945 & \\
\hline
\end{tabular}

Table 5. Electronic spectral data of Fe(III) complexes(5-8)

\begin{tabular}{cccccc}
\hline \multirow{2}{*}{ Com. No. } & \multicolumn{2}{c}{ Complexes } & \multicolumn{4}{c}{ Spectral band $\left(\mathrm{cm}^{-1}\right)$ with assignment } \\
\cline { 3 - 6 } & & ${ }^{6} \mathrm{~A}_{1 \mathrm{~g}} \rightarrow{ }^{4} \mathrm{~T}_{1 \mathrm{~g}}(\mathrm{G})$ & ${ }^{6} \mathrm{~A}_{1 \mathrm{~g}} \rightarrow{ }^{4} \mathrm{~T}_{2 \mathrm{~g}}(\mathrm{G})$ & ${ }^{6} \mathrm{~A}_{1 \mathrm{~g}} \rightarrow{ }^{4} \mathrm{E}_{\mathrm{g}}(\mathrm{G})$ & ${ }^{6} \mathrm{~A}_{1 \mathrm{~g}} \rightarrow{ }^{4} \mathrm{~A}_{1 \mathrm{~g}}(\mathrm{G})$ \\
\hline 5 & $\mathrm{~K}\left[\mathrm{Fe}(\mathrm{III})(\mathrm{MA})_{2}(\mathrm{py})_{2}\right]$ & 18725 & 21000 & 24325 & 25770 \\
6 & $\mathrm{~K}\left[\mathrm{Fe}(\mathrm{III})(\mathrm{MA})_{2}(4-\mathrm{pico})_{2}\right]$ & 18500 & 21185 & 24750 & 25640 \\
7 & $\mathrm{~K}\left[\mathrm{Fe}(\mathrm{III})(\mathrm{MA})_{2}(\mathrm{Q})_{2}\right]$ & 18625 & 21050 & 24550 & 25675 \\
8 & $\mathrm{~K}\left[\mathrm{Fe}(\mathrm{III})(\mathrm{MA})_{2}(\mathrm{IQ})_{2}\right]$ & 18675 & 21150 & 24645 & 25750 \\
\hline where, & $\mathrm{MA}=\mathrm{C}_{4} \mathrm{H}_{4} \mathrm{O}_{5}$, & $\mathrm{Py}=\mathrm{C}_{5} \mathrm{H}_{5} \mathrm{~N}$, & $4-\mathrm{pico}=\mathrm{C}_{6} \mathrm{H}_{7} \mathrm{~N}$, & $\mathrm{Q}=\mathrm{C}_{9} \mathrm{H}_{7} \mathrm{~N}$, & $\mathrm{IQ}=\mathrm{C}_{9} \mathrm{H}_{7} \mathrm{~N}$
\end{tabular}

Table 6. Antibacterial activity of complexes(1-8)

\begin{tabular}{|c|c|c|c|c|c|c|c|c|c|c|}
\hline \multirow{2}{*}{$\begin{array}{c}\text { Bacteria } \\
\text { code }\end{array}$} & \multirow{2}{*}{ Name of the bacteria } & \multicolumn{9}{|c|}{ Diameter of inhibition zone of bacteria in different complexes* $(\mathrm{mm})$} \\
\hline & & 1 & 2 & 3 & 4 & 5 & 6 & 7 & 8 & 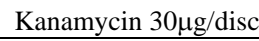 \\
\hline A001 & Staphylococcus aureus & 0 & 16 & 8 & 16 & 0 & 20 & 8 & 17 & 22 \\
\hline B001 & Strptococcus- $\beta$-haemolyticus & 14 & 15 & 0 & 16 & 8 & 11 & 0 & 14 & 18 \\
\hline C001 & Bacillus megaterium & 13 & 31 & 12 & 20 & 12 & 18 & 10 & 18 & 25 \\
\hline D001 & Bacillus subtilis & 12 & 9 & 22 & 12 & 0 & 8 & 10 & 8 & 24 \\
\hline E001 & Sarcina lutea & 18 & 32 & 16 & 16 & 10 & 10 & 10 & 10 & 23 \\
\hline F001 & Salmonella typhi & 10 & 18 & 16 & 20 & 12 & 14 & 20 & 14 & 19 \\
\hline G001 & Shigella dysenteriae & 14 & 30 & 16 & 20 & 19 & 13 & 10 & 10 & 20 \\
\hline H001 & Shigella boydii & 21 & 26 & 20 & 22 & 0 & 12 & 0 & 12 & 24 \\
\hline I001 & Shigella flexneri & 13 & 31 & 12 & 16 & 12 & 18 & 10 & 18 & 18 \\
\hline J001 & Shigella sonnei & 15 & 10 & 16 & 14 & 12 & 10 & 0 & 10 & 23 \\
\hline K001 & Shigella shiga & 8 & 12 & 20 & 24 & 8 & 28 & 10 & 30 & 26 \\
\hline L001 & Klebsiella sp & 0 & 9 & 20 & 10 & 0 & 8 & 8 & 8 & 21 \\
\hline M001 & Psudomonas aeruginosa & 8 & 18 & 12 & 14 & 10 & 11 & 10 & 10 & 20 \\
\hline N001 & Escherichia coli & 8 & 15 & 10 & 8 & 10 & 8 & 0 & 8 & 20 \\
\hline
\end{tabular}

*Complexes name see Table 1 
Table 7. Antifungal activity of the complexes(1-8)

\begin{tabular}{|c|c|c|c|c|c|c|c|c|c|c|}
\hline \multirow{2}{*}{$\begin{array}{l}\text { Fungi } \\
\text { code }\end{array}$} & \multirow{2}{*}{ Name of the fungi } & \multicolumn{9}{|c|}{ Diameter of inhibition zone of fungi in different complexes* (mm) } \\
\hline & & 1 & 2 & 3 & 4 & 5 & 6 & 7 & 8 & Fluconazol \\
\hline A002 & Fusarium sp. & 0 & 7 & 0 & 8 & 8 & 0 & 0 & 0 & 15 \\
\hline B002 & Trichophyton sp. & 7 & 28 & 8 & 0 & 10 & 0 & 8 & 0 & 0 \\
\hline C002 & Penicillium sp. & 0 & 8 & 0 & 6 & 8 & 7 & 0 & 0 & 22 \\
\hline D002 & Mucor sp. & 0 & 8 & 0 & 0 & 8 & 0 & 0 & 0 & 0 \\
\hline E002 & Aspergillus flavus & 0 & 10 & 0 & 8 & 0 & 0 & 0 & 0 & 22 \\
\hline F002 & Aspergillus terreas & 0 & 8 & 7 & 0 & 8 & 0 & 0 & 0 & 10 \\
\hline G002 & Aspergillus versicolar & 7 & 8 & 0 & 10 & 10 & 0 & 7 & 0 & 0 \\
\hline H002 & Aspergillus niger & 0 & 0 & 0 & 0 & 0 & 0 & 0 & 7 & 22 \\
\hline $\mathrm{I} 002$ & Aspergillus nidulans & 8 & 8 & 0 & 8 & 0 & 0 & 0 & 0 & 18 \\
\hline J002 & Candida albicans & 0 & 0 & 0 & 0 & 0 & 0 & 0 & 0 & 0 \\
\hline K002 & Trichoderma virude & 8 & 8 & 0 & 10 & 0 & 8 & 0 & 6 & 16 \\
\hline L002 & Colletotrichum falcatum & 0 & 0 & 0 & 0 & 8 & 0 & 0 & 0 & 35 \\
\hline M002 & Bipolaris sorokiniana & 0 & 30 & 8 & 8 & 0 & 10 & 8 & 0 & 18 \\
\hline N002 & Sclerotium rolfsii & 0 & 0 & 0 & 0 & 8 & 0 & 0 & 6 & 28 \\
\hline
\end{tabular}

\section{Conclusion}

From the above discussion the structure of Co(II) and $\mathrm{Fe}(\mathrm{III})$ complexes are assignable tetrahedral and of octahedral respectively. Similarly the structure of other complexes may also be given. Some of these complexes(1-8) demonstrated strong antibacterial and antifungal activities.

\section{References}

Islam, M.S., Hossain, M.B. and Reza, M.Y. 2004. Synthesis and characterization of mixed-ligand complexes of $\mathrm{Co}(\mathrm{II})$ and $\mathrm{Fe}(\mathrm{III})$ ions with malonic acid and heterocyclic amines. Indian. J. Chem. 43, 1897-1900.

Catalina, R., Joaqu,, S., Molina., M.H., Lloret, F. and Julve M. 2000. Ferromagnetism in malonato-bridged copper(II) complexes. Synthesis, crystal structures, and magnetic properties of $\{[\mathrm{Cu}(\mathrm{H} 2 \mathrm{O})(3)][\mathrm{Cu}(\mathrm{mal})(2) \quad(\mathrm{H} 2 \mathrm{O})]\}(\mathrm{n}) \quad$ and $\quad\{[\mathrm{Cu}(\mathrm{H} 2 \mathrm{O})(4)]$ $(2)[\mathrm{Cu}(\mathrm{mal})(2)(\mathrm{H} 2 \mathrm{O})]\} \quad[\mathrm{Cu}(\mathrm{mal})(2)(\mathrm{H} 2 \mathrm{O})(2)]\{[\mathrm{Cu}(\mathrm{H} 2 \mathrm{O})(4)][\mathrm{Cu}$ $(\mathrm{mal})(2)(\mathrm{H} 2 \mathrm{O})(2)]\}(\mathrm{H}(2) \mathrm{mal}=$ malonic acid). J. Inorg. Chem. 39, 1363-1370.

Zakaria, C.M., Farrouque, A., Islam, M.R., Islam, M.A. and Biswas, M.H., 2000. Antimicrobial screening of ferrocene derivative compounds. Oriental J. Chem. 16, 85-90.

Islam, M.S., Farooque, M.A., Bodruddoza, M.A.K. and Mosaddik, M.A. 2002. Antimicrobial and toxicological studies of mixed ligand transition metal complexes of Schiff bases. J. Bio. Sci. 2, 797-799.

Part, W.B., and Ruddon, W. 1979. The Anticancer Drugs. 1st Edn., Oxford University Press, Oxford, New York, PP 251-254.

Sultana, C.M., Rahman, A.A., Al-Bari, M.A.A., Banu, M.L.A., Islam, M.S., Khatune, N.A. and Sadik, G. 2003. In Vitro Antimicrobial Screening of Three Cadmium Coordination Complexes and Two Addition Compounds Antimony and Arsenic. Pak. J. Biol. Sci. 6, 525-527.
Nippon Synthetic Chemical Industry Co. Ltd. Japan, Germicides, Fungicides and Preservative Composition, 02 July 1980. Jpn Koai Tikkyo Koho 8087708 (C. 1. AOIW 47/04).

Bhatia, P.K., Gaur, Y.D. and Rao, N.S.S. 1993. Hydrogen uptake among fast and slow growing rrizotia/Bradyrihizbia pigeonpea cultivars. Pl. Physiol, Biochem. 19, 30-32.

Reza, M.Y., Hossain, M.B., Islam, M.S. and Alam, S. 2003. Antimicrobial studies of mixed ligand transition metal complexes of malonic acid and heterocyclic amine bases. Pak. J. Biol. Sci. 6(15), 1314-1316.

Reza, M.Y., Hossain, M.B. and Islam, M.S. 2003. Antimicrobial studies of mixed ligand transition metal complexes of phthalic acid and heterocyclic amine bases. Pak. J. Biol. Sci. 6, 1494-1496.

Islam, M.S., Hossain, M.B. and Reza, M.Y. 2003. Antimicrobial studies of mixed ligand transition metal complexes of maleic acid and heterocyclic amine bases. J. Med. Sci. 3, 289-293.

Scargill, D. 1961. J. Chem. Soc. 42, 4440.

Vogel, V.I. 1961. A Text-Book of Quantitative Inorganic Analysis. $3^{\text {rd }}$ edn. ELBS and Longmans, Green \& Co. Ltd. London.

Beur, A.W., Jkirby W.M.M. and Turck, M. 1966. Modified ultra filtration method fordetg serum protein binding and its application to penicillin. Am. J. Clin. Pathol. 44, 493-496.

Rios, J.J., Reico, M.C. and Villar, A. 1988. Antimicrobial screening of natural products, Journal of Ethnopharmacology. J. Entho. Pharmacol. 23, 127-159.

Hossain, M.B., Hossain, M.M, and Islam, M.S. 2004. Synthesis and characterization of the mixed ligand complexes of Pt(IV) and Ni(II) ions with phthalic acid and heterocyclic amines. J. Bangladesh Chem. Soc. 17, 177-182.

Shekh, C., Hossain, M.B., Hossain, M.A., Nasrin, J. and Islam, M.S. 2004. Preparation and characterization of some mixed ligand complexes of $\mathrm{Cr}(\mathrm{III})$ with phthalimide of succinimide and amino acids. J. Bangladesh Chem. Soc. 17, 90-95.

Hossain, M.B., Hassan, M.N, Yousuf, M.A. and Salam,M.A. 2008. Antimicrobial activity studies of mixed ligand metal complexes of some dibasic acid and heterocyclic bases. Dhaka Univ. J. Pharm. Sci. 7, 153-156. 